\title{
Aspects of the effect of metiamide on pentagastrin- stimulated and basal gastric secretion of acid and pepsin in man
}

\author{
B. THJODLEIFSSON AND K. G. WORMSLEY ${ }^{1}$ \\ From the Department of Therapeutics, University of Dundee
}

SUMMARY This study has examined the inhibition produced by metiamide on the gastric secretion of acid and pepsin in 13 patients with duodenal and three with gastric ulcer. The effect of metiamide on the response to a range of doses of pentagastrin in three normal individuals was determined, as was the interaction of metiamide and atropine on prolonged basal secretion. Metiamide inhibited the secretion of acid more than pepsin and the gastric secretion of patients with gastric ulcer more than duodenal ulcer. Metiamide inhibited both the maximal secretory response attainable with pentagastrin and decreased the sensitivity to pentagastrin. Atropine augmented and prolonged the action of metiamide.

Metiamide, an $\mathrm{H}_{2}$-receptor antagonist (Black, Duncan, Durant, Ganellin, and Parsons, 1972), has been shown to inhibit the basal (Konturek, Biernat, and Oleksy, 1974; Mainardi, Maxwell, Sturdevant, and Isenberg, 1974), nocturnal (Milton-Thompson, Jenkins, Williams, and Misiewicz, 1974; Thjodliefsson and Wormsley, 1974), and pentagastrinstimulated (Konturek et al, 1974; Thjodleifsson and Wormsley, 1974) secretion of acid and pepsin from the human stomach. The present study has sought to examine different aspects of the pharmacological basis of the gastric secretory inhibition produced by metiamide and has also attempted to provide a basis for assessing the dose requirements of metiamide in the treatment of peptic ulcer.

\section{Methods and Patients}

Thirteen patients with duodenal ulcer and three patients with gastric ulcer, in all of whom the diagnosis had been confirmed endoscopically, were invited to take part in the study. All gave informed consent. After an overnight fast, gastric contents were aspirated for $\mathbf{2 0}$ minutes through a modified nasogastric (Ryle's) tube. Pentagastrin was then given by constant-rate intravenous infusion at a

'Please address communications to: KGW, Ninewells Hospital, Dundee DD2 1 UB

Received for publication 14 May 1975. rate of $2 \mu \mathrm{g} / \mathrm{kg}$ body weight-hour for 165 minutes. Gastric contents were aspirated continuously in 11 batches of 15 minutes each. During the period from 60 to 120 minutes (periods 4 to 8 ) after starting the pentagastrin infusion, $200 \mathrm{mg}$ metiamide (tritiated at the 2 position of the imidazole ring and dissolved in $0.15 \mathrm{M}$ sodium chloride) was given in a separate infusion into the same arm as the pentagastrin infusion. Blood for measurement of the metiamide concentration was taken from the opposite arm before the start of the metiamide infusion and then at 15-minute intervals until the end of the test.

In order to assess the relevance of the blood concentrations of metiamide attained by intravenous infusion of the drug, blood concentrations were measured at 30,60,120,240, and 360 minutes after oral administration of $200 \mathrm{mg}$ tritiated metiamide, given immediately after breakfast. In eight of the patients with duodenal ulcer who were undergoing treatment with the drug, blood concentrations were again measured after the same oral dose of tritiated metiamide, following treatment for one to three weeks.

In three normal subjects (medical students) the relationship between gastric secretion and dose of pentagastrin was determined by giving $0.05,0 \cdot 2,1 \cdot 0$, and $4.0 \mu \mathrm{g} / \mathrm{kg}$-hour pentagastrin for 60 minutes on separate days and aspirating gastric contents in 15-minute batches. The same dose schedule was then repeated twice for each subject in order to study the 
effect of two dose levels of metiamide, except that the lowest dose of pentagastrin was not given during administration of the higher dose of metiamide because secretory inhibition was almost complete with the second lowest dose of pentagastrin. The metiamide was given intravenously 10 minutes before the start and during the course of the pentagastrin infusion in two dose schedules: (I) an intravenous bolus dose of $75 \mathrm{mg}$ followed by continuous infusion of $30 \mathrm{mg}$ during 60 minutes; and (II) an intravenous bolus dose of $20 \mathrm{mg}$, followed by continuous infusion of $30 \mathrm{mg}$ during 60 minutes.

The two dose schedules had been calculated to give approximately steady blood concentrations of metiamide of 6 to 8 and 1 to $3 \mu \mathrm{M}$ respectively. The calculations were confirmed by direct monitoring of the blood levels during the test.

In two patients with duodenal ulcer an attempt was made to establish a possible therapeutic basis for augmenting the gastric inhibitory action of metiamide by the use of anticholinergic drugs.

The tests started in the morning after an overnight fast. Each patient was intubated with a modified nasogastric (Ryle's) tube. Resting gastric contents were discarded. The following experimental schedules were employed :

1 The control tests involved collection of 30minute batches of basal (unstimulated) gastric contents for at least four hours.

2 After control collection for at least 30 minutes, tritiated metiamide was given intravenously in a dose of $75 \mathrm{mg}$ and followed by continuous infusion of metiamide at a rate of 40 or $80 \mathrm{mg}$ per hour (for subjects SP and AM, respectively) for one hour. Blood was taken for measurement of concentrations of metiamide at five, $30,60,90,120$, and 240 minutes after starting the infusion. Gastric aspiration was continued throughout and for $2 \frac{1}{2}$ and $3 \frac{1}{2}$ hours, respectively, after the infusion.

3 After the control collection, metiamide was infused in doses as in (2). At the same time, atropine was given intravenously in a single injection of 0.6 mg. Gastric aspiration was continued as in (2).

4 Subject SP had one further test. After controlled collection, atropine was given-intravenously in a single injection of $0.6 \mathrm{mg}$. Gastric aspiration was continued as in (2).

The concentration of acid in all samples of gastric juice was determined by automatic titration with $0 \cdot 1 \mathrm{M}$ sodium hydroxide to $\mathrm{pH} 7 \cdot 0$. The activity of pepsin was measured by the method of Hunt (1948). (In the remainder of the text, 'peptic activity' will be referred to as 'pepsin'.) The concentration of metiamide was measured by scintillation counting of an octanol extract of the blood.

The statistical analyses were carried out according to Snedecor and Cochran (1967) as appropriate, using the two-tailed paired ' $t$ ' test; comparison of means of unequal samples with unequal variances; and linear regression using the method of least squares.

\section{CALCULATIONS}

\section{Intravenous infusion of metiamide}

The mean output of acid and pepsin during the two 15-minute periods preceding the metiamide infusion (periods 3 and 4) has been taken as control and is referred to as $100 \%$. The proportional (percentage) inhibition in all subsequent periods was calculated as follows:

$100-\left(S_{x} .100\right) /\left(\left[S_{3}+S_{4}\right] / 2\right)$-where $S_{x}=$ output of acid (or pepsin) in period $x$ and $\left[S_{3}+S_{4}\right] / 2$ $=$ mean output of acid (or pepsin) during control periods. Blood concentrations of metiamide during each period were assumed to be the arithmetic mean of the levels at the beginning and the end of the respective period. The blood concentration of metiamide required to achieve $50 \%$ inhibition (IC50) was calculated for each patient by least squares regression analysis of $\log [(\%$ inhibition $) /(100$ - \% inhibition)] on log blood concentration of metiamide for periods 7 to 11 . Logit 0 (intercept of regression line with $x$-axis) gave $\log \mathrm{IC}_{50}$. The value of IC $_{50}$ for acid secretion could not be calculated for three patients. In one individual, the gstric aspirate remained alkaline during metiamide infusion and IC $_{50}$ was considered to be less than $1 \mu \mathrm{M}$. In the other two subjects, the inhibition remained constant at 76 to $80 \%$ and 95 to $98 \%$ respectively for all concentrations of metiamide and extrapolation to $50 \%$ inhibition was therefore impossible. The value of $\mathrm{IC}_{50}$ for pepsin secretion could not be calculated for five patients because linear regression was not significant, due to the pattern of the time course of the interaction between metiamide and pepsin secretion.

\section{Effect of metiamide on dose response to pentagastrin}

The results from the three students were pooled. For each dose, the outputs during the last 30 minutes of each test were compared. For the purpose of comparison, gastric acid secretion in response to different doses of pentagastrin has been analysed in terms of Michaelis-Menten kinetics. In order to obtain the most accurate kinetic constants, the transformation of the Michaelis-Menten equation suggested by Dowd and Riggs (1965) was used to calculate $\mathrm{ED}_{50}$ (dose of pentagastrin required for $50 \%$ of maximal secretion) and CMR (calculated maximal response) according to the equation: response $=\mathrm{CMR}-\mathrm{ED}_{50}$ (response/dose). 
Least squares linear regression of response/dose (abscissa) against response (ordinate) gave estimates of CMR $\left(y-\right.$ intercept) and $\mathrm{ED}_{50}$ (negative slope).

\section{Inhibition of basal secretion}

The inhibition of basal secretion was calculated for each period from the corresponding period in the control test, according to the formula: percentage inhibition $=100-\left[\left(S_{x} .100\right) / S_{c}\right]$ where $S_{x}$ is the secretion in the test period and $S_{c}$ in the corresponding control period.

\section{Results}

\section{INTRAVENOUS METIAMIDE}

Results from the 13 patients with duodenal ulcer (DU) were analysed separately from the pooled results of the three patients with gastric ulcer (GU). Gastric secretion of acid and pepsin in the patients with GU was inhibited more than in patients with DU by all concentrations of metiamide (fig 1 ). The

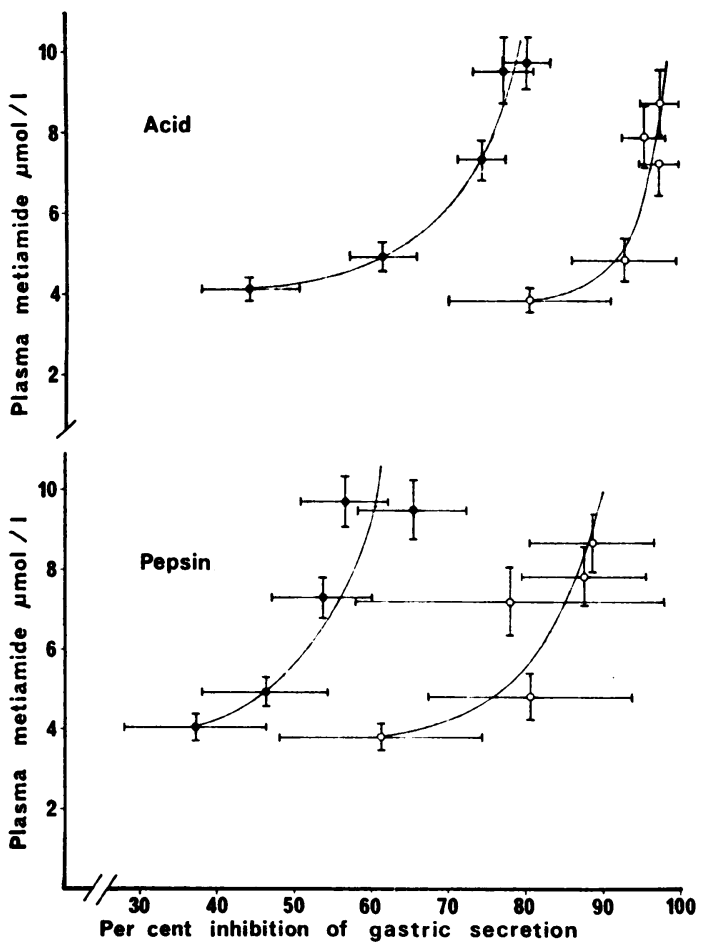

Fig 1 Relationship between concentration of metiamide in blood and inhibition of secretion of acid and pepsin.

Each point represents mean values $( \pm S E M)$ derived as described in the text. The closed circles indicate results from patients with duodenal ulcer; the open circles, from patients with gastric ulcer. The lines joining the points have been fitted by visual inspection

\begin{tabular}{|c|c|c|c|c|}
\hline \multirow[t]{2}{*}{ Patient No. } & \multicolumn{2}{|l|}{ Acid } & \multicolumn{2}{|c|}{ Pepsin } \\
\hline & $I C_{50}{ }^{1}$ & $r$ & $I C_{50}$ & $r$ \\
\hline 1 & 5.93 & 0.79 & $7 \cdot 55$ & 0.74 \\
\hline 2 & $4 \cdot 13$ & 0.95 & $7 \cdot 18$ & 0.95 \\
\hline $3(\mathrm{GU})$ & 1.53 & 0.87 & $2 \cdot 14$ & 0.67 \\
\hline 4 & 4.95 & 0.89 & $4 \cdot 86$ & 0.95 \\
\hline 5 & $5 \cdot 55$ & 0.91 & 5.46 & 0.73 \\
\hline 6 & 5.80 & $0 \cdot 70$ & - & - \\
\hline $7(\mathrm{GU})$ & 1.0 & - & $1 \cdot 70$ & 0.98 \\
\hline 8 & $3 \cdot 50$ & 0.93 & 5.90 & 0.83 \\
\hline 9 & 6.40 & 0.62 & - & - \\
\hline $10(\mathrm{GU})$ & $2 \cdot 65$ & 0.93 & 4.95 & 0.70 \\
\hline 11 & $2 \cdot 12$ & 0.81 & $7 \cdot 54$ & 0.35 \\
\hline 12 & $2 \cdot 50$ & 0.87 & - & - \\
\hline 13 & - & - & - & - \\
\hline 14 & $5 \cdot 60$ & 0.85 & $11 \cdot 30$ & 0.87 \\
\hline 15 & - & - & - & - \\
\hline 16 & $3 \cdot 80$ & 0.99 & $3 \cdot 33$ & 0.53 \\
\hline Overall mean & 3.96 & & 5.63 & \\
\hline SD & 1.79 & & 2.75 & \\
\hline GU mean & 1.73 & & 2.93 & \\
\hline SD & 0.84 & & 1.76 & \\
\hline DU mean & 4.57 & & $6 \cdot 64$ & \\
\hline SD & 1.45 & & $2 \cdot 38$ & \\
\hline
\end{tabular}

Table Kinetic analysis of inhibitory effects of plasma levels of metiamide on pentagastrin-stimulated secretion of acid and pepsin by the stomach

${ }^{1} \mathrm{IC}_{30}=$ dose of metiamide $(\mu \mathrm{mol} / \mathrm{l})$ necessary to elicit $50 \%$ inhibition of pentagastrin-stimulated secretion of acid or pepsin.

maximal inhibition of the secretion of acid and pepsin was significantly greater in the patients with GU than DU $(P<0.05)$. The inhibition of pepsin secretion was less than acid secretion at all concentrations of metiamide and the maximal degree of inhibition of pepsin secretion was significantly less than acid secretion in both groups of patients (DU$P<0.01$; GU-P < 0.05).

The IC 50 of metiamide was significantly higher for pepsin secretion than for acid secretion in all individuals considered together (table) $(P<0.025)$ and in the group of DU patients alone $(P<0.05)$. The group of GU patients had a significantly lower $\mathrm{IC}_{50}$ for acid secretion than the patients with DU $(\mathrm{P}<0.05)$ but the $\mathrm{IC}_{50}$ for pepsin secretion was not significantly different in the two groups.

The IC $_{50}$ for inhibition of acid secretion by metiamide showed positive correlation with the acid-secretory response to pentagastrin when the results from all patients (DU and GU) were considered together (fig 2$)(r=0.72 ; P<0.01)$ but the correlation was not significant for the DU group alone. The correlation between pepsin-secretory response and $\mathrm{IC}_{50}$ for pepsin secretion was not significant.

ORAL DOSE OF METIAMIDE

Since the results were homogeneous, for clarity of presentation only the results from the eight patients 


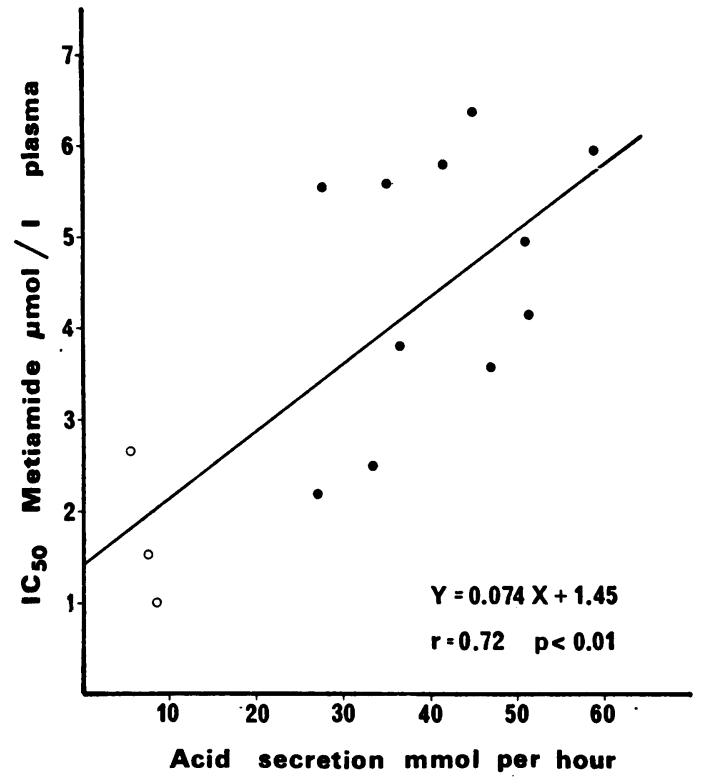

Fig 2 Relationship between $I C_{50}$ for inhibition of acid secretion by metiamide and acid-secretory response to pentagastrin.

Closed circles denote results from patients with duodenal ulcer; open circles from patients with gastric ulcer

who had tests before and during treatment with metiamide are shown (fig 3). The blood concentrations of metiamide rose more rapidly and remained higher after the second dose of metiamide (given during the course of treatment) than after the first dose. The difference between the two sets of blood concentrations was greatest at $\mathbf{3 0}$ minutes but did not reach levels of significance.

EFFECT OF METIAMIDE ON DOSE RESPONSE TO PENTAGASTRIN

\section{Acid secretion}

The mean CMR to pentagastrin was progressively depressed from the control value of 16.2 to 8.9 $\mathrm{mmol} / 30$ minutes with schedule II dosage of metiamide and further reduced to $6.1 \mathrm{mmol} / 30$ minutes with schedule I dosage (fig 4). The ED 50 of pentagastrin increased from the control value of $0 \cdot 15$ to $0.32 \mu \mathrm{g} / \mathrm{kg}$-hour (schedule II) and to $0.90 \mu \mathrm{g} / \mathrm{kg}$-hour for schedule $I$.

\section{Pepsin secretion}

The mean peak output for the three students in the control tests was achieved with $1.0 \mu \mathrm{g} / \mathrm{kg}$-hour pentagastrin. The highest dose of pentagastrin

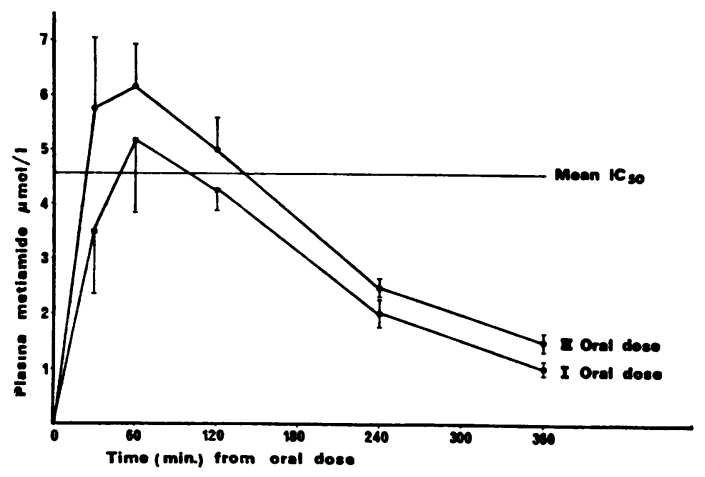

Fig 3 Concentrations of metiamide in blood after oral dosage, before, and during treatment.

Each point represents mean values $( \pm S E M)$ of concentrations in blood of eight subjects. The pretreatment test is denoted by the symbol I and the test during treatment with metiamide by II.

The horizontal line depicts, for patients with duodenal ulcer, the mean $I C_{50}$ for inhibition of pentagastrinstimulated acid secretion by metiamide.

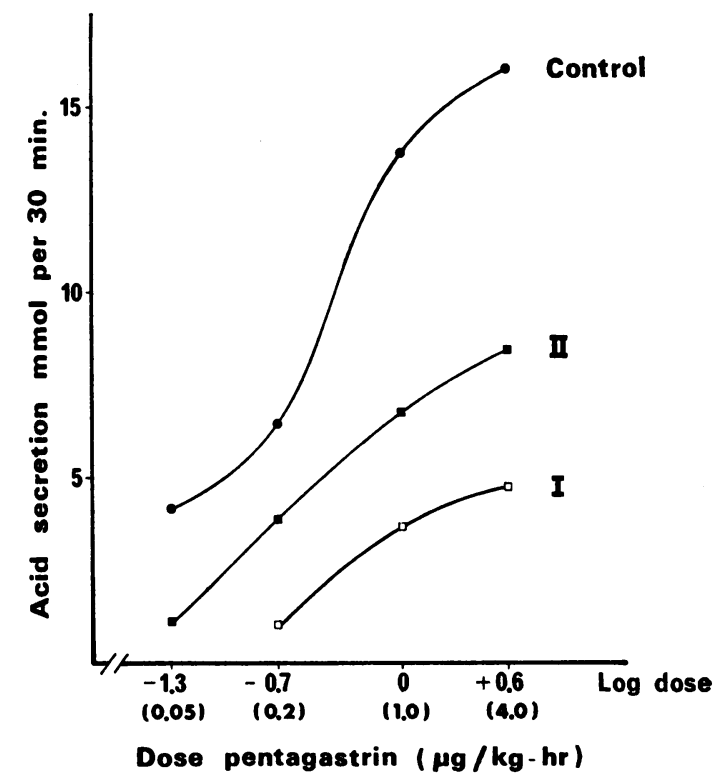

Fig 4 Acid secretion in response to increasing doses of pentagastrin, without and with metiamide.

Each point represents the mean values from three subjects. The closed circles indicate the control dose-response relationship between acid secretion and dose of pentagastrin; the closed squares indicate the dose-response pattern with the smaller dose of metiamide and the open squares indicate the dose response relationship during administration of the larger dose of metiamide.

The log dosage of pentagastrin is depicted along the abscissa; the arithmetic values of the doses are shown in parentheses 


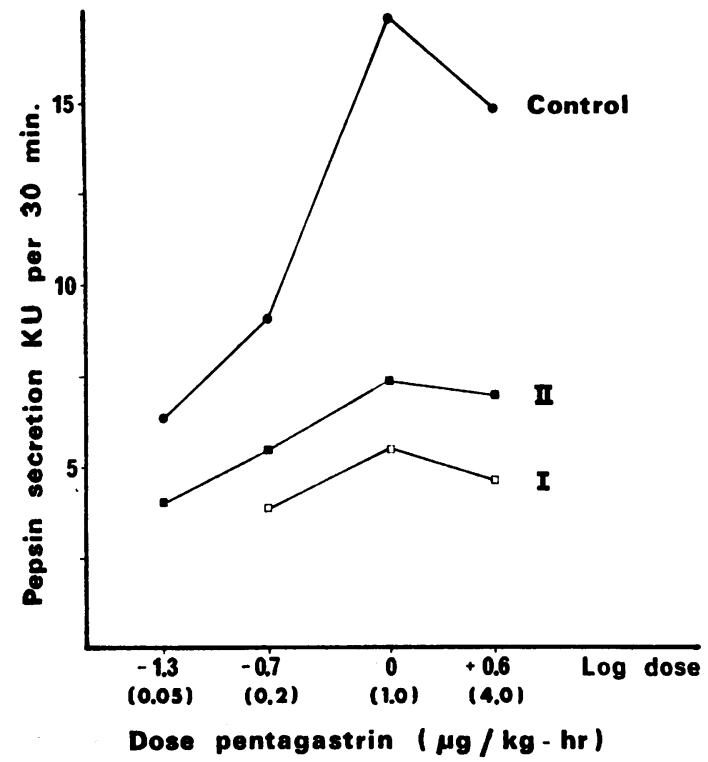

Fig 5 Pepsin secretion in response to increasing doses of pentagastrin, without and with metiamide.

Significance of symbols as in figure 4 resulted in lower pepsin outputs (fig 5). Kinetic analysis was therefore not possible. The lower dose of metiamide (schedule II) resulted in mean inhibition of 35 and $42 \%$ for the two lowest doses of pentagastrin and 58 and $53 \%$ respectively for the two highest doses. For dose schedule I, the mean inhibition was 59,68 , and $68 \%$ respectively.

EFFECTS OF METIAMIDE AND ATROPINE ON BASAL GASTRIC SECRETION

During the course of prolonged aspiration of basal gastric secretion in subject SP, there was a greater degree of inhibition of acid than pepsin secretion both by metiamide (mean inhibition of acid $=83.2 \%$ and of pepsin $=27.5 \%$ ) and by atropine (mean inhibition $74.0 \%$ and $39.8 \%$ respectively). Basal gastric secretion was abolished for $2 \frac{1}{2}$ hours by the combination of the two drugs (fig 6).

In subject AM, the higher dose of metiamide alone had a greater inhibitory effect than in patient SP, but secretion of acid and pepsin had similarly returned to control levels within 90 minutes after discounting the infusion of metiamide. The addition of atropine abolished the rebound secretion (fig 7).
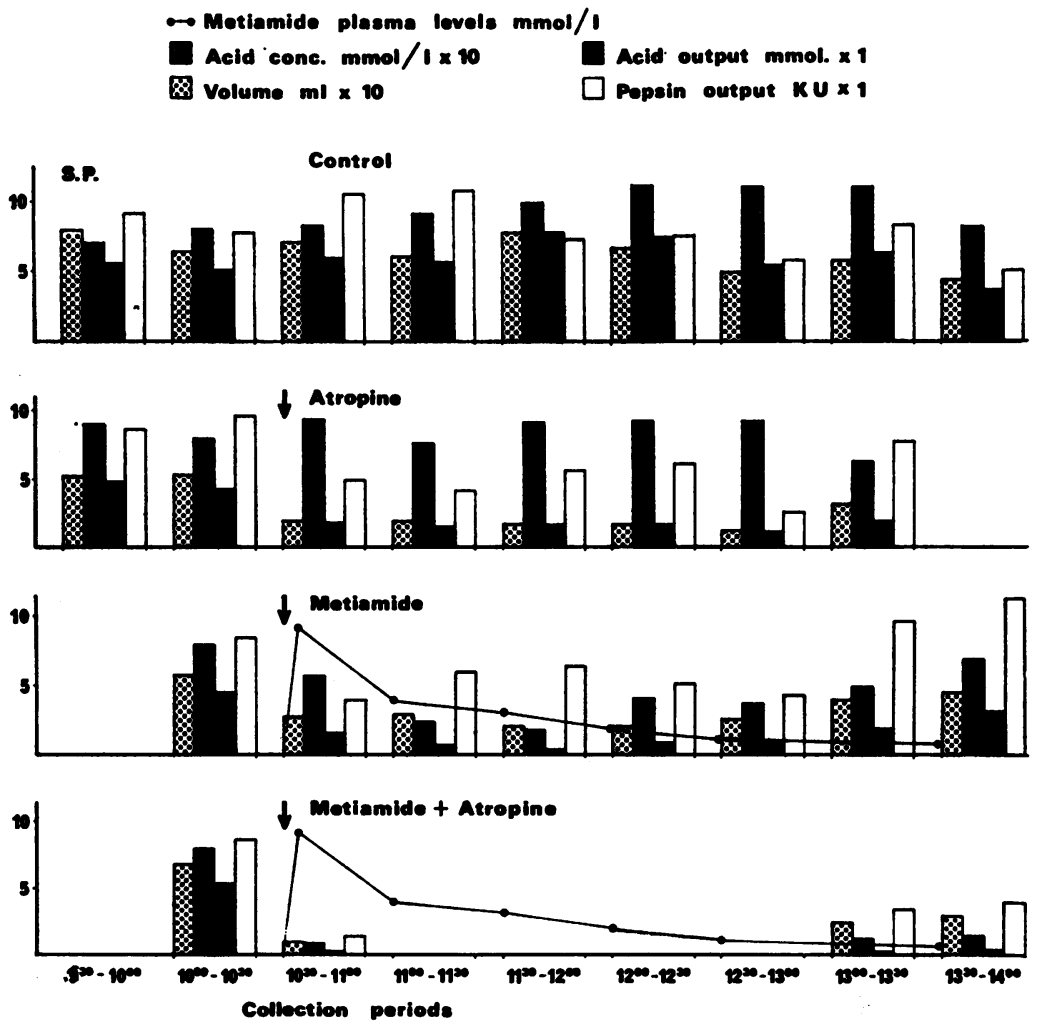

Fig 6 Time course of basal secretion of gastric juice in patient $S P$.

Each set of four columns represents values for volume (dots), acid concentration (cross hatch), acid output (solid bars) and pepsin output (open bars) during a 30-minute collection period, the timing of which is depicted along the abscissa. Atropine, metiamide, or the combination of drugs was given, as described in the text, at the time indicated by the arrow.

The closed circles indicate the concentration of metiamide in blood 

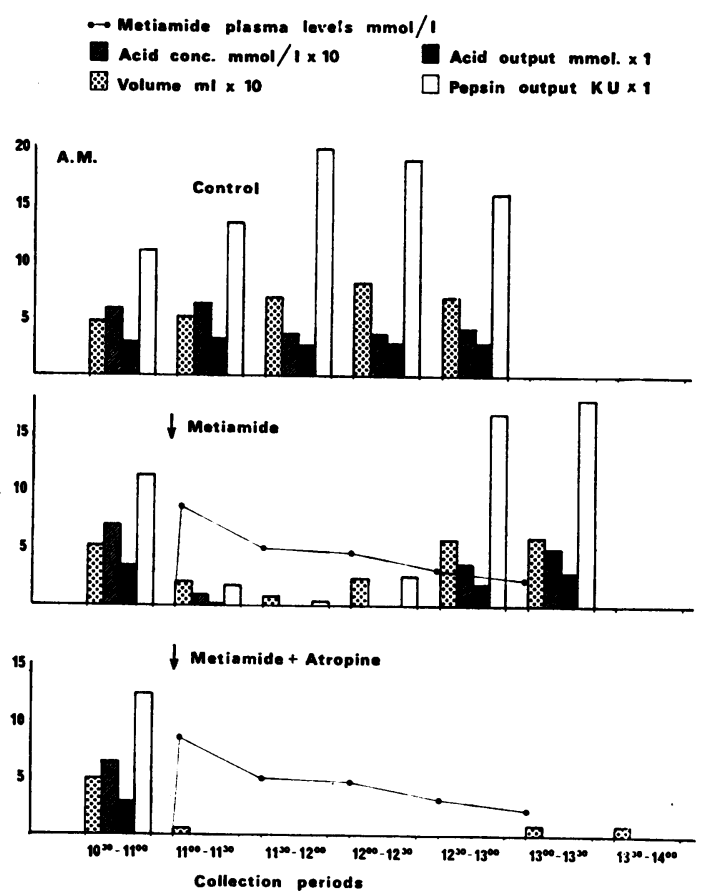

Fig 7 Time course of basal secretion of gastric juice in patient $A M$.

Significance of symbols as in figure 6

\section{Discussion}

GASTRIC INHIBITORY EFFECT OF METIAMIDE IN PATIENTS WITH DUODENAL OR GASTRIC ULCER

The dose of metiamide used in the present study had previously been shown to inhibit acid secretion in normal subjects by $87 \%$, a value intermediate between our patients with duodenal ulcer $(80 \%)$ and gastric ulcer $(97 \%)$. The degree of inhibition of gastric acid secretion has previously been shown to be inversely related to the intensity of stimulation of the stomach (Code and Watkinson, 1955) and since patients with duodenal ulcer tend to be more sensitive to stimulants than normal (Isenberg, Grossman, Maxwell, and Walsh, 1975), it seems possible that the dose of pentagastrin $(2 \mu \mathrm{g} / \mathrm{kg}$-hour $)$ used in the present study may have provided a relatively greater degree of stimulation for patients with duodenal ulcer, resulting in the lesser inhibitory effect of metiamide in the patients with duodenal ulcer compared with those with gastric ulcer. An alternative explanation is provided by the lower values of $\mathrm{IC}_{50}$ (concentration of metiamide required to achieve $50 \%$ inhibition) in our patients with gastric ulcer compared with duodenal ulcer, a finding which is compatible with greater 'sensitivity' of gastric ulcer patients to the gastric inhibitory action of metiamide, or greater relative 'resistance' to metiamide of patients with duodenal ulcer.

\section{INHIBITORY EFFECT OF METIAMIDE ON SECRETION OF ACID AND PEPSIN}

The present study has confirmed our previous observation (Thjodleifsson and Wormsley, 1974) that metiamide inhibits gastric secretion of acid more than secretion of pepsin in man. The relatively greater inhibitory effect of metiamide on acid, compared with pepsin, secretion results mainly from change in the pattern of secretion of the two components of gastric juice, since the concentration of acid, but not of pepsin, decreases during inhibition by metiamide (Thjodleifsson and Wormsley, 1974).

More detailed examination of the inhibitory effect of metiamide involved the use of doses of the drug which gave blood concentrations respectively greater and less than the $\mathrm{IC}_{50}$. We used a linear transformation of the Michaelis-Menten equation for estimation of the 'kinetic constants' $V_{\max }$, which in gastric secretory terms is the CMR (calculated maximal response) and $\mathrm{K}_{\mathrm{m}}$, which in terms of interaction between stimulant and gastric response is the $E_{50}$ (dose of pentagastrin required to stimulate secretion at half the maximal rate), since description in terms derived from kinetic analysis of enzymically controlled biochemical reactions has been found useful for describing and comparing pharmacological reactions such as the gastric secretory responses to stimulants and inhibitors (Makhlouf, McManus, and Card, 1966; Grossman, 1970). If a gastric secretory inhibitor increases the $\mathrm{ED}_{50}$ but leaves the CMR unchanged, then the interaction between inhibitor and stimulant is considered to be competitive, while reduction in the CMR is considered to show non-competitive antagonism between the drugs.

In the present study, metiamide affected the acidsecretory response to increasing doses of pentagastrin in three normal subjects both by decreasing the calculated maximal response and by increasing the dose of pentagastrin required to elicit the halfmaximal secretory rate. The higher of the two blood levels had a greater effect on both aspects of the gastric secretory response (higher ED 50 , lower CMR) than the lower blood level. The antagonism on acid secretion between metiamide and pentagastrin is therefore 'mixed type'. Metiamide also decreased the calculated maximal pepsin response to pentagastrin, although an approximate estimate of the $\mathrm{ED}_{50}$ for pepsin showed little change. In dogs, the inhibitory effect of metiamide has similarly been 
interpreted as 'uncompetitive', both with histamine and pentagastrin as stimulant, since $\mathrm{ED}_{50}$ was markedly increased and CMR reduced by metiamide (Gibson, Hirschowitz, and Hutchison, 1974). In man and dog metiamide, therefore, both decreases the total capacity of the stomach to respond to pentagastrin and decreases the sensitivity of the acidsecreting cells to pentagastrin.

The implications of the mixed competitive and non-competitive pattern of the effect of metiamide on pentagastrin- and histamine-stimulated gastric secretion have complicated the hypothesis that metiamide acts only by blocking the action of drugs on the $\mathrm{H}_{2}$-receptors of the parietal cells. Black (1973) proposed the presence of both excitatory and inhibitory receptors to pentagastrin on the parietal cells and showed how a pattern suggestive of noncompetitive interaction might result if the inhibitory action of pentagastrin were more difficult to activate than the excitatory effect. We have recently suggested that if the effects of metiamide cannot be explained by blockade of the $\mathrm{H}_{2}$-receptors alone, then our recent confirmation in man (Shepherd, Thjodleifsson, Turnbull, and Wormsley, 1974) of the finding in vitro that metiamide stimulates histamine methyl transferase (Barth, Niemeyer, and Lorenz, 1973) may indicate a further possible mechanism for the complex action of metiamide on gastric secretion.

\section{DOSAGE OF METIAMIDE REQUIRED FOR}

\section{GASTRIC INHIBITION}

The blood concentration of metiamide required to obtain $50 \%$ inhibition of pentagastrin-stimulated secretion of acid has been found to range from less than 1 to $6.4 \mu \mathrm{mol} / \mathrm{l}$, so that dose requirements for inhibition may differ appreciably between individuals. The present study has shown that there is a correlation between a wide range of acid-secretory capacity and $\mathrm{IC}_{50}$ (dose of metiamide required to produce $50 \%$ inhibition) in our combined population of patients with gastric or duodenal ulcers. If the correlation represents the pattern in the population as a whole (and is not fortuitously caused by the selection and combination of a 'sensitive' (GU) and 'resistant' (DU) population) then measurement of acid secretory capacity may serve as a guide to dose requirement of metiamide.

INHIBITORY INTERACTION OF METIAMIDE AND ATROPINE

In accordance with the requirements of the Clinical Trials Certificate, higher doses of metiamide were not used in the present study, so that we have no information about the limits, if any, of the inhibitory action of metiamide on acid secretion. However, our findings show that atropine augments and prolongs the gastric inhibition produced by metiamide, so that very satisfactory long-continued suppression of basal gastric secretion is provided by the combination of the two drugs.

ORAL ADMINISTRATION OF METIAMIDE

The present study has shown that the blood concentrations of metiamide, attained by intravenous infusion of the drug and shown to effect gastric inhibition, are also achieved after oral administration of the drug. The transintestinal passage of metiamide does not appear to affect significantly the chemical nature or gastric inhibitory action of metiamide. Thus, similar values for concentrations were obtained by measurement of the levels of the tritiated drug in the present study compared with direct chemical analysis by high pressure liquid chromatography in two subjects (unpublished results). The similar pharmacological (gastric inhibitory) efficacy of the two modes of administration of metiamide had been demonstrated previously (Thjodleifsson and Wormsley, 1974) when it was shown that a similar degree of gastric inhibition was achieved by intravenous and intraintestinal administration of the drug.

Pharmacological analysis based on the response to intravenously administered metiamide is therefore relevant to the utilization of the drug in tablet form.

During treatment with metiamide, the blood concentration after an oral load of $200 \mathrm{mg}$ remained above the mean $\mathrm{IC}_{50}$ for duodenal ulcer for $2 \frac{1}{2}$ hours. A dose of $200 \mathrm{mg}$ given after the three main meals would therefore probably achieve more than $50 \%$ secretory inhibition during the interdigestive periods of the day in patients with average acid-secretory capacities (30 to $40 \mathrm{mM} /$ hour). Given after meals, blood concentrations of metiamide would be greatest at a time when the buffering effect of the meal itself was diminishing. These theoretical results have been borne out by the recent study of Richardson, Baily, Walsh, and Fordtran (1975) who investigated the inhibition by metiamide of mealstimulated gastric secretion directly.

A previous study had shown that adequate inhibition of nocturnal gastric secretion was achieved, in most patients suffering from duodenal ulcer, with $\mathbf{4 0 0} \mathrm{mg}$ metiamide, given as a single dose (Milton-Thompson et al, 1974), or in divided doses during the night (Thjodleifsson and Wormsley, 1974). The findings of the present study that atropine augments and prolongs the gastric inhibitory effect of metiamide extends our previous observation that when nocturnal gastric secretion is not satisfactorily controlled with this dose of metiamide, the degree of gastric inhibition can be increased by atropine (Thjodleifsson and Wormsley, 1974). 


\section{Conclusion}

The powerful inhibitory action of metiamide on gastric secretion suggests that the drug may be valuable in the treatment of diseases in which secretion of acid and pepsin is thought to play an aetiological role. The degree of reduction of secretion of acid and pepsin which has to be achieved in order to permit healing of the mucosal lesions has not been defined. However, the majority of duodenal and gastric ulcers heal after vagotomy, which reduces acid-secretory capacity by $50 \%$ (Jepson, Lari, Humphrey, Smith, Wilkinson, and Johnston, 1973). That the healing of ulcers after vagotomy is indeed due to the reduction in the secretion of acid and pepsin, rather than to some other effect of the operation, seems likely in view of the healing which has been observed after treatment with metiamide in doses which have produced similar degrees of reduction of gastric secretion (Thjodleifsson and Wormsley, 1975).

KGW is in receipt of a grant from the Scottish Hospital Endowments Research Trust. The metiamide was kindly supplied by $\mathrm{Dr} \mathrm{M}$. Bloch of Smith, Kline and French Laboratories, Ltd, Welwyn Garden City. The authors wish to thank Miss W. Ealding for estimation of tritiated metiamide, and Mrs F. Deer and Miss S. Drummond for technical assistance.

\section{References}

Barth, H., Niemeyer, I., and Lorenz, W. (1973). Studies on the mechanism of inhibition of gastric histamine methyl transferase by $\mathrm{H}_{1}$ - and $\mathrm{H}_{2}$-receptor antagonists. In International Symposium on Histamine $\mathrm{H}_{2}$-Receptor Antagonists, edited by C. J. Wood and M. A. Simkins, pp. 115-123. Smith, Kline, and French Laboratories Ltd, Welwyn Garden City.

Black, J. W. (1973). Speculation about the nature of the antagonism between metiamide and pentagastrin. In International Symposium on Histamine $\mathrm{H}_{2}$-Receptor Antagonists, edited by C. J.
Wood and M. A. Simkins, pp. 219-221. Smith, Kline, and French Laboratories Ltd, Welwyn Garden City.

Black, J. W., Duncan, W. A. M., Durant, C. J., Ganellin, C. R., and Parsons, M. E. (1972). Definition and antagonism of histamine $\mathrm{H}_{2}$-receptors. Nature (Lond.), 236, 385-390.

Black, J. W., Duncan, W. A. M., Emmett, J. C., Ganellin, C. R. Hesselbo, T., Parsons, M. E., and Wyllie, J. H. (1973). Metiamide-an orally active histamine $\mathbf{H}_{\mathbf{2}}$-receptor antagonist. Agents and Actions, 3, 133-137.

Code, C. F., and Watkinson, G. (1955). Importance of vagal innervation in the regulatory effect of acid in the duodenum on gastric secretion of acid. $J$. Physiol. (Lond.), 130, 233-252.

Dowd, J. E., and Riggs, D. S. (1965). A comparison of estimates of Michaelis-Menten kinetic constants from various linear transformations. J. biol. Chem., 240, 863-869.

Gibson, R., Hirschowitz, B. I., and Hutchison, G. (1974). Actions of metiamide, an $\mathrm{H}_{2}$-histamine receptor antagonist, on gastric $\mathrm{H}^{+}$ and pepsin secretion in dogs. Gastroenterology, 67, 93-99.

Grossman, M. I. (1970). Gastrin, cholecystokinin, and secretin act on one receptor. Lancet, 1, 1088-1089.

Hunt, J. N. (1948). A method for estimating peptic activity in gastric contents. Biochem. J., 42, 104-109.

Isenberg, J. I., Grossman, M. I., Maxwell, V., and Walsh, J. H. (1975) Increased sensitivity to stimulation of acid secretion by pentagastrin in duodenal ulcer. $J$. clin. Invest., 55, 330-337.

Jepson, K., Lari, J., Humphrey, C. S., Smith, R. B., Wilkinson, A. R. and Johnston, D. (1973). A comparison of the effects of truncal, selective and highly selective vagotomy on maximal acid output in response to pentagastrin. Ann. Surg., 178, 769-772.

Konturek, S. J., Biernat, J., and Oleksy, J. (1974). Effect of metiamide, a histamine $\mathrm{H}_{2}$-receptor antagonist, on gastric response to histamine, pentagastrin, insulin, and peptone meal in man. Amer. J. dig. Dis., 19, 609-616.

Mainardi, M., Maxwell, V., Sturdevant, R. A. L., and Isenberg, J. I. (1974). Metiamide, an $H_{2}$-receptor blocker, as inhibitor of basal and meal-stimulated gastric acid secretion in patients with duodenal ulcer. New Engl. J. Med., 291, 373-376.

Makhlouf, G. M., McManus, J. P. A., and Card, W. I. (1966). A quantitative statement of the two-component hypothesis of gastric secretion. Gastroenterology, 51, 149-171.

Milton-Thompson, G. J., Williams, J. G., Jenkins, D. J. A., and Misiewicz, J. J. (1974). Inhibition of nocturnal acid secretion in duodenal ulcer by one oral dose of metiamide. Lancet, 1 , 693-694.

Richardson, C. T., Bailey, B. A., Walsh, J. H., and Fordtran, J. S. (1975). The effect of an $\mathrm{H}_{2}$-receptor antagonist on foodstimulated acid secretion, serum gastrin, and gastric emptying in patients with duodenal ulcers. J. clin. Invest., 55, 536-542.

Shepherd, D. M., Thjodleifsson, B., Turnbull, M. J., and Wormsley, K. G. (1974). Effect of metiamide on histamine metabolism in man. Digestion, 11, 307-310.

Snedecor, G. W., and Cochran, W. G. (1967). Statistical Methods. 6th ed. Iowa State University Press, Ames.

Thjodleifsson, B., and Wormsley, K. G. (1974). Gastric response to metiamide. Brit. med. J., 2, 304-306.

Thjodleifsson, B., and Wormsley, K. G. (1975). Effects of long term treatment with metiamide. Digestion, in press. 